\title{
Vitamin D in Preclinical Models of Fatty Liver Disease
}

\author{
ERSIN KARATAYLI, CAROLINE S. STOKES and FRANK LAMMERT
}

Department of Medicine II, Saarland University Medical Center, Saarland University, Homburg, Germany

\begin{abstract}
Simple steatosis in non-alcoholic fatty liver disease (NAFLD) progresses to non-alcoholic steatohepatitis (NASH) when excessive fat accumulation is accompanied by ballooning, inflammation, and progressive hepatocellular injury. Due to the increasing global incidence of NAFLD/NASH and the lack of effective drugs, current treatment options are currently dominated by lifestyle interventions, including dietary and physical activity modifications. In this regard, vitamin $D$ has received widespread attention in recent years. In line with its pleiotropic physiological effects, preclinical animal models and patient cohorts have demonstrated anti-inflammatory, anti-fibrotic and anti-proliferative effects of vitamin $D$ on NAFLD and NASH. Several animal models have confirmed the association of vitamin D deficiency and NALFD/NASH severity in humans and revealed potential benefits of dietary vitamin D supplementation. These preclinical models also provide critical guidance to define the roles and therapeutic potential of vitamin $D$ as well as its downstream functional mechanisms in the pathogenesis of fatty liver disease. This review summarizes vitamin $D$ research in currently available animal models of fatty liver disease.
\end{abstract}

Non-alcoholic steatohepatitis (NASH) was first introduced to medical terminology by Ludwig et al. in 1980 to describe an unknown liver disease that histologically mimics alcoholic fatty liver disease in patients with no history of alcohol abuse (1). Since then, increasing evidence has demonstrated that NASH is a severe form of non-alcoholic fatty liver disease (NAFLD), which is distinct from simple

Correspondence to: Assoc.-Prof. Ersin Karatayli, Ph.D., Department of Medicine II, Saarland University Medical Center, Saarland University, Kirrberger Str., 66421 Homburg, Germany. Tel: +49 68411615020, Fax: +49 68411615021, e-mail: ersin.karatayli@uks.eu

Key Words: Animal models, vitamin D, non-alcoholic fatty liver disease, non-alcoholic steatohepatitis, review. fatty liver (hepatic steatosis), since it is characterized by necro-inflammation, hepatocellular ballooning and progressive tissue damage in addition to hepatic fat deposition, which may lead to liver cirrhosis and hepatocellular carcinoma. Due to the global increasing incidence of NAFLD/NASH (2) and limited therapeutic options, lifestyle modifications such as increased physical activity and dietary-related interventions remain important treatment strategies (3). Currently, vitamin D, with its direct anti-inflammatory, anti-proliferative and anti-fibrotic effects shown in experimental studies $(4,5)$, is a promising nutrient for the treatment of NAFLD/NASH, since it is commonly deficient in chronic liver diseases (6). Moreover, vitamin D has been reported to be associated with NAFLD/NASH in several epidemiological studies $(7,8)$. Longitudinal cohort studies and randomized controlled trials offer ideal methodological designs to confirm these protective effects of vitamin D on liver diseases (9). However, such clinical trials are to a great extent hampered by the slow nature of disease progression (10) and the wide spectrum of disease stages of NAFLD/NASH, which are difficult to differentiate noninvasively (11). Hence, various animal models of fatty liver disease that mimic human pathobiology have been developed for vitamin D research. As summarized in Table I, these preclinical models largely depend on diet-induced liver injury, however a limited number of chemically induced and alcohol-induced fatty liver disease models are also listed as well as those that depend on the genetic background of the animals. The aim of this review is to present an overview of vitamin $\mathrm{D}$ research in current experimental fatty liver disease models to better understand the role and therapeutic potential of vitamin D and its effects on the pathogenesis and the course of the disease.

\section{Vitamin D in Fatty Liver Disease}

Vitamin D is a fat-soluble secosteroid that is metabolized in the liver and kidney and is converted to the $1,25(\mathrm{OH})_{2} \mathrm{D}_{3}$ active form (calcitriol) in the body (Figure 1). As calcitriol, vitamin $\mathrm{D}$ acts as a sterol hormone that regulates diverse 
Table I. Vitamin D research in preclinical models of fatty liver disease.

\begin{tabular}{|c|c|c|c|c|c|c|}
\hline Disease & Animal model & Cause for liver injury & VitD suppl & VitD ther & Notes & Ref. \\
\hline \multicolumn{7}{|l|}{ Diet-induced liver injury } \\
\hline NAFLD & $\mathrm{BALB} / \mathrm{c}$ mice & - Control chow with $\mathrm{VD}_{3}$ & + & - & & (32) \\
\hline NASH & $V d r^{-/-}$mice & $\begin{array}{l}\text { - Vitamin D depleted control chow } \\
\text { - High fat diet with } \mathrm{VD}_{3} \\
\text { - HFD without } \mathrm{VD}_{3}\end{array}$ & & & & \\
\hline NASH & Sprague-Dawley rats & - HFD & - & + & & (33) \\
\hline NAFLD & Sprague-Dawley rats & - HFD & - & + & & (53) \\
\hline NAFLD & C57BL/6 mice & $\begin{array}{l}\text { - Low fat vitamin D replete (LFD+) } \\
\text { - Low fat vitamin D deficient (LFD-) } \\
\text { - High fat vitamin D replete (HFD+) }\end{array}$ & & & & \\
\hline & & - High fat vitamin D deficient (HFD-) & + & - & & $(54)$ \\
\hline Hypercholesterolemia & $\begin{array}{l}F x r^{-/-} \text {mice } \\
\text { Shp } p^{-/-} \text {mice } \\
\text { C57BL/6 mice }\end{array}$ & - Western diet & - & + & & (37) \\
\hline NASH & Balb/C mice & $\begin{array}{l}\text { - } \mathrm{HFD} \\
\text { - } \mathrm{VD}_{3} \text { depleted HFD }\end{array}$ & - & + & & (34) \\
\hline Metabolic syndrome & Wistar rats & - HFD & - & + & $\begin{array}{l}\text { Vitamin D is } \\
\text { administered alone } \\
\text { and in combination } \\
\text { with metformin }\end{array}$ & $(55)$ \\
\hline NASH & Lewis rats & $\begin{array}{l}\text { Choline-deficient, L-amino } \\
\text { acid-defined and iron- } \\
\text { supplemented diet (CDAA) }\end{array}$ & - & + & $\begin{array}{l}\text { Vitamin D is applied } \\
\text { either orally or } \\
\text { by phototherapy }\end{array}$ & $(41)$ \\
\hline Obesity-related NASH & C57BL/6 mice & $\begin{array}{l}\text { - } \text { LFD } \\
\text { - } \text { High fat/high sugar Surwit diet (HFHS) } \\
\text { - } \mathrm{HFHS}+\mathrm{VD}_{3} \text { diet }\end{array}$ & + & - & & $(56)$ \\
\hline NAFLD & C57BL/6 mice & - Methionine and choline- & - & + & & $(44)$ \\
\hline NASH & $\begin{array}{c}A p o E^{-/-} \text {mice } \\
V d r^{-/-} \text {mice } \\
\text { Apo } E^{-/-} V d r^{-/-} \text {mice }\end{array}$ & $\begin{array}{l}\text { deficient diet (MCD) } \\
\text { - HFD }\end{array}$ & & & & \\
\hline $\begin{array}{l}\text { Hyperinsulinemia } \\
\text { and steatosis }\end{array}$ & ICR mice & $\begin{array}{l}\text { - Vitamin D depleted control diet } \\
\text { - HFD } \\
\text { - Vitamin D depleted HFD }\end{array}$ & - & - & & $(57)$ \\
\hline $\begin{array}{l}\text { Diabetes induced } \\
\text { liver injury }\end{array}$ & Sprague-Dawley rats & - HFHS & - & + & $\begin{array}{l}\text { Streptozotocin is } \\
\text { applied to induce } \\
\text { diabetes }\end{array}$ & $(58)$ \\
\hline Obesity-related & Sprague-Dawley rats & $\cdot \mathrm{HFD}$ & - & - & & $(42)$ \\
\hline NAFLD & & $\begin{array}{l}\text { - Western diet (high fructose } \\
\text { corn syrup (HFCS) + HFD) } \\
\text { - Vitamin D depleted Western diet or HFD }\end{array}$ & & & & \\
\hline NASH & Wistar rats & - Choline-deficient diet & + & + & & (35) \\
\hline NAFLD & Wistar rats & $\begin{array}{l}\text { - High fat/high fructose diet (HFHF) } \\
\text { - HFHF + vitamin D }\end{array}$ & + & - & $\begin{array}{c}\text { Vitamin D } \\
\text { administration in } \\
\text { diet is supplemented } \\
\text { by IP injections } \\
\text { of metformin }\end{array}$ & $(59)$ \\
\hline Steatosis & Wistar rats & - HFHF & + & - & $\begin{array}{l}\text { Vitamin D } \\
\text { is applied together } \\
\text { with calcium in } \\
\text { increasing doses }\end{array}$ & $(60)$ \\
\hline Steatosis & C57BL/6 mice & • HFD & - & + & & (38) \\
\hline Steatosis & Sprague-Dawley rats & $\begin{array}{l}\text { - } 35 \% \text { fructose solution } \\
\text { - } 35 \% \text { fructose solution + vitamin D }\end{array}$ & - & + & $\begin{array}{l}\text { Rats are fed standard } \\
\text { chow diet and } \\
\text { solutions are applied } \\
\text { by oral gavage }\end{array}$ & $(52)$ \\
\hline $\begin{array}{l}\text { Metabolic } \\
\text { syndrome }\end{array}$ & $\begin{array}{l}L d l r^{-/-} \text {and } L d l r^{+/+} \\
\text {C57BL/6 mice }\end{array}$ & $\begin{array}{l}\text { - Diabetogenic diet (DD) } \\
\text { - } \mathrm{DD}+\text { vitamin D }\end{array}$ & + & - & & (61) \\
\hline Steatosis & Sprague-Dawley rats & - HFD & - & + & & (39) \\
\hline
\end{tabular}


Table I. Continued

\begin{tabular}{|c|c|c|c|c|c|c|}
\hline Disease & Animal model & Cause for liver injury & VitD suppl & VitD ther & Notes & Ref. \\
\hline \multicolumn{7}{|c|}{ Chemically-induced liver injury } \\
\hline Liver fibrosis & Wistar rats & Thioacetamide & - & + & $\begin{array}{l}\text { Bile duct ligation } \\
\text { is also applied for } \\
\text { induction of } \\
\text { liver fibrosis }\end{array}$ & $(62)$ \\
\hline Hepatocarcinogenesis & Wistar rats & $\begin{array}{l}\text { Diethylnitrosamine } \\
\text { followed by } \mathrm{CCl}_{4} \text { injections }\end{array}$ & - & + & & (63) \\
\hline $\begin{array}{l}\text { Diabetes induced } \\
\text { liver injury }\end{array}$ & Sprague-Dawley rats & Streptozotocin & - & + & & (43) \\
\hline \multicolumn{7}{|l|}{ Monogenic liver injury } \\
\hline Obesity-related NASH & Zucker $f a / f a$ rats & - & - & + & $\begin{array}{l}\text { Vitamin D is } \\
\text { applied via } \\
\text { phototherapy }\end{array}$ & (41) \\
\hline $\begin{array}{l}\text { Cholestatic liver } \\
\text { disease }\end{array}$ & $\begin{array}{c}A b c b 4^{-/-} \\
\text {FVB/NJ mice }\end{array}$ & - & - & + & & $(30)$ \\
\hline \multicolumn{7}{|l|}{ Alcoholic liver injury } \\
\hline ND & Long Evans rats & $\begin{array}{l}\text { Liquid diet containing Sustacal } \\
\text { and ethanol for } 10 \text { months }\end{array}$ & - & + & & (64) \\
\hline Alcoholic liver disease & C57BL/6 mice & Ethanol diet for 6 weeks & - & + & & (65) \\
\hline
\end{tabular}

Abcb4: ATP binding cassette transporter B4; Apoe: apolipoprotein E; CDAA: choline-deficient, L-amino acid-defined diet; DD: diabetogenic diet; Fxr: farnesoid X receptor (bile acid receptor); HFD: high fat diet; HFHF: high fat, high fructose diet; HFHS: high fat, high sucrose diet; IP: intraperitoneal; Ldlr: low-density lipoprotein receptor; LFD: low fat diet; MCD: methionine and choline-deficient diet; NAFLD: non-alcoholic fatty liver disease; NASH: non-alcoholic steatohepatitis; Shp: short heterodimer partner; $\mathrm{VD}_{3}$ : vitamin $\mathrm{D}_{3}$ (calcitriol); Vdr: vitamin $\mathrm{D}$ receptor; VitD suppl: vitamin D supplementation prior to/during establishment of liver injury; VitD ther: vitamin D rescue therapy after the establishment of liver injury; ND: not determined; Ref: reference.

biological events, ranging from host immune responses to cellular differentiation in addition to its classical role in calcium and bone metabolism (12). Therefore, it is not surprising that a growing body of evidence links vitamin D deficiency (VDD) with multiple inflammatory (13) and chronic disorders (14), including chronic liver diseases (15). In this regard, various studies have demonstrated that VDD is more common and associated with the severity and disease progression in patients with NAFLD/NASH (16-22). Although two meta-analyses $(7,8)$ and a recent study in a large cohort of Korean patients with NAFLD (23) confirmed these findings, it is noteworthy to state that several studies have presented contradictory results with no significant association between serum vitamin $\mathrm{D}$ concentrations and fatty liver disease phenotypes (24-27). These controversies may be, at least in part, explained by the heterogeneity of the criteria used for NAFLD diagnosis and VDD, as well as differences in vitamin D assays. Nevertheless, future prospective randomized clinical trials in patients with NAFLD/NASH can be envisioned.

\section{Vitamin D Research in Preclinical Models of Fatty Liver Disease}

Given the conflicting results in human studies, animal models of fatty liver disease gain more importance when it comes to the potential to provide critical guidance in delineating causal roles and the therapeutic potential of vitamin D on disease pathogenesis and progression. Several in vivo and in vitro studies have revealed that vitamin D and its receptor (VDR) are involved in repressing hepatic stellate cell (HSC) activation, thereby inhibiting the primary driver of hepatic fibrogenesis $(4,28,29)$. Consistent with these findings, we have demonstrated that low-vitamin D diet-fed Abcb4 knockout mice develop more advanced biliary fibrosis and elevated collagen deposition (30). Feeding these mice a high-vitamin $\mathrm{D}$ diet led to an increase in serum vitamin $\mathrm{D}$ concentrations, which simultaneously lowered liver enzyme activities, altered the expression levels of profibrogenic genes, and ameliorated, in part, liver injury. A more recent in vitro study has further confirmed the inhibition of HSC activation by vitamin D 


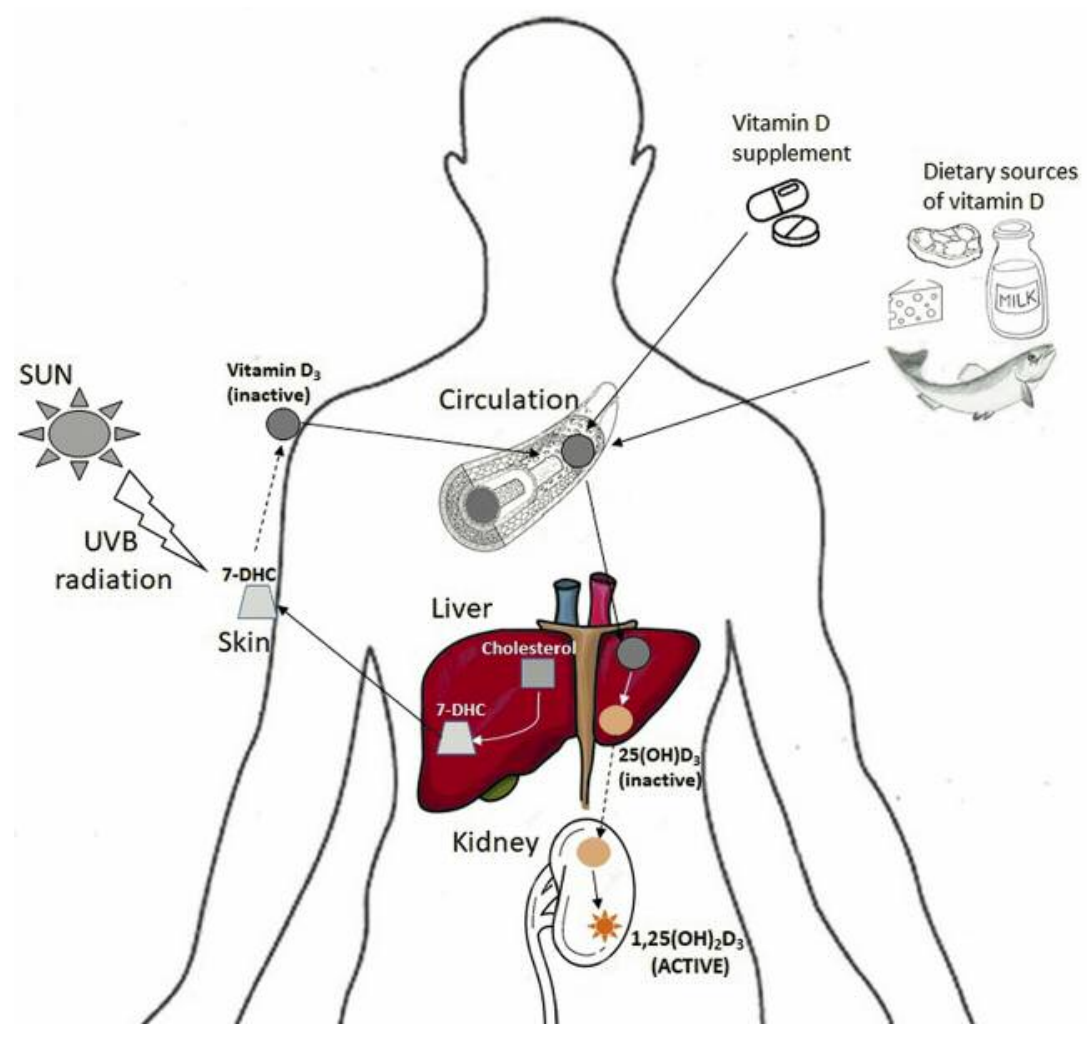

Figure 1. Vitamin D synthesis and activation. Cholesterol is metabolized to 7-dehydrocholesterol (7-DHC) in liver, which is further converted to vitamin $D_{3}$ (cholecalciferol, an inactive form of vitamin D) in the skin when exposed to UVB radiation via sunlight. In addition to photosynthesis, vitamin $D$ is also acquired by dietary intake and supplementation, entering the blood stream after intestinal absorption. Vitamin D is then converted to $1,25(\mathrm{OH})_{2} \mathrm{D}_{3}$ (active form) through sequential hydroxylation steps in liver and kidney. 7-DHC: 7-dehydrocholesterol; 25(OH)D $\mathrm{D}_{3}$ : 25hydroxyvitamin $D_{3}$ (calcidiol); $1,25(\mathrm{OH})_{2} D_{3}: 1,25$ dihydroxyvitamin $D_{3}$ (calcitriol, active form of vitamin D); UVB: ultraviolet radiation in wavelength region $B(320-290 \mathrm{~nm})$.

through transforming growth factor (TGF)- $\beta$ signaling in primary human HSC, supporting the anti-fibrotic effect of vitamin D (31).

Su et al. (32) have demonstrated that feeding BALB/c male mice a vitamin D-deficient, high fat diet resulted in overt insulin resistance and NASH phenotypes with aggravated systemic and local inflammation, whereas sufficient vitamin D supplementation ameliorated the histopathological changes with less insulin resistance and moderate hepatic steatosis. This study also revealed a critical role of the vitamin D/VDR axis in suppressing NASH progression by maintaining intestinal integrity through the induction of defensins and tight junction genes. Similarly, a recent study has reported the reduction of tumor necrosis factor (TNF)- $\alpha$-mediated immunological abnormalities and hepatic steatosis in a high fat diet rodent model of NASH with chronic calcitriol supplementation (33). Another experimental study has demonstrated that VDD plus high fat diet impairs the enterohepatic circulation of bile acids, resulting in NASH in
$\mathrm{BALB} / \mathrm{c}$ inbred mice via repression of the ileal apical sodiumdependent bile acid cotransporter [Asbt=Solute carrier 10A2 (Slc10a2)] (34). Of note, the NASH phenotype was corrected by administration of calcitriol, which restored ileal Slc10a2 expression and reduced hepatic inflammation and steatosis. In line with these findings, Han et al. (35) have demonstrated that $1,25(\mathrm{OH})_{2} \mathrm{D}_{3}$ supplementation in rats with NASH induced by choline-deficient diet resulted in the reduction of cytokeratin 18 apoptotic fragment M30, which is a bona fide marker for liver injury (36). Additionally, a shift of bile acid metabolism to lower cholesterol levels by down-regulation of small heterodimer protein (Shp=Nuclear receptor 0B2) and upregulation of cholesterol $7 \alpha$-hydroxylase $(C y p 7 a 1)$ through intraperitoneal (IP) injections of $1,25(\mathrm{OH})_{2} \mathrm{D}_{3}$ was observed in mice on Western diet (37). Moreover, $1,25(\mathrm{OH})_{2} \mathrm{D}_{3}$ has also been shown to ameliorate hepatic steatosis by autophagy through the induction of autophagy-related-16-like 1 (Atg 16l1) protein (38), the inhibition of lipogenesis and the promotion of fatty acid oxidation in vivo (39). These preventive and 
therapeutic effects of vitamin D have also been reported in a number of experiments using phototherapy, which increased the concentrations of active circulating vitamin $\mathrm{D}$ in serum $(40,41)$. Nakano et al. (41) have reported the suppression of apoptosis, inflammation and fibrosis in NASH models Lewis rats on choline-deficient, L-amino acid-defined and ironsupplemented diet (CDAA) as well as in obesity-related NASH (Zucker $\mathrm{fa} / \mathrm{fa}$ rats). These changes were reflected by lower serum aminotransferase activities and hepatic triglyceride levels, the suppression of inflammatory and fibrotic genes such as TNF- $\alpha$, TGF- $\beta$ and $\alpha$-Smooth muscle actin, and an increase in serum adiponectin levels. Interestingly, both skin exposure to ultraviolet radiation and the supplementation of CDAA-fed rats with $1 \alpha(\mathrm{OH}) \mathrm{D}_{3}(0.4$ $\mu \mathrm{g} / \mathrm{kg}$ orally 3 times/week) resulted in a similar phenotype. Roth et al. (42) have provided additional evidence on the immune-regulatory role of vitamin D in NAFLD in obese Sprague-Dawley rats. Liver histopathology in these rats revealed that vitamin D-depleted Western diet resulted in increased lobular inflammation and higher NAFLD activity scores, accompanied by elevated expression of hepatic resistin, interleukins (IL) 1 $1 \beta, 4$ and 6 and Toll-like receptors (TLR) 2, 4 and 9 as well as the oxidative stress marker heme oxygenase 1 (HO-1), suggesting that VDD may lead to elevated endotoxin exposure, exacerbated inflammatory pathways, and increased oxidative stress, which subsequently aggravate NAFLD. In line with these results, suppression of TLR4mediated inflammation and amelioration of liver injury have been observed in diabetic rats treated with $1,25(\mathrm{OH})_{2} \mathrm{D}_{3}(43)$.

\section{Factors Involved in Vitamin D Metabolism in Experimental Models of Fatty Liver Disease}

Further studies in experimental models suggest that not only vitamin $\mathrm{D}$ but also related factors involved in vitamin $\mathrm{D}$ metabolism are associated with NAFLD/NASH. Bosic et al. (44) have investigated hepatic $V d r$ expression in two mouse models of fatty liver disease, i.e. apolipoprotein E knock-out $\left(\right.$ Apo $\left.^{-/-}\right)$mice on a high fat diet and wild-type mice on methionine and choline-deficient (MCD) diet as well as in patients with NAFLD and NASH. Similar to the mouse models, hepatic VDR expression in livers from NAFLD patients was markedly increased in the setting of hepatosteatosis, but decreased in NASH, suggesting an early role of $V D R$ induction in the pathogenesis of fatty liver diseases. Early induction of VDR in NAFLD was also found to modulate key hepatic lipid regulatory genes with decreased expression of CD36,DGAT2,C/EBP $\alpha$ and $F G F 21$, and increased expression of PNPLA2, LIPIN1 and $P G C 1 \alpha$. Moreover, using a double knock-out $A p o E^{-/} V d r^{-/}$ mice, they have demonstrated that the deletion of VDR prevents diet-induced fatty liver. Convincing evidence on the key role of VDR in NAFLD pathogenesis has been provided by Ding et al. (45) in a preclinical model of $V d r^{-1-}$ mice, showing that VDR ligands inhibit HSC activation by abrogating TGF- $\beta$-induced fibrotic gene signatures through a VDR/SMAD "genomic circuit", whereas $V d r$ knock-out mice spontaneously develop hepatic fibrosis.

Furthermore, normalization of VDR and SMAD3 binding in the presence of both calcipotriol and TGF $\beta 1$ to their basal levels revealed that the occupancy of VDR and SMAD3 were inversely correlated, suggesting TGF $\beta$-induced chromatin accessibility produces a genomic architecture that facilitates VDR to reverse SMAD activation.

Another factor in vitamin D metabolism, vitamin D binding protein (DBP), binds to vitamin D metabolites and acts as a reservoir, in particular for $25(\mathrm{OH}) \mathrm{D}(46,47)$. DBP thereby helps to ameliorate VDD. Proteomics analysis in a NASH model of $\mathrm{C} 57 \mathrm{BL} / 6 \mathrm{~J}$ male mice fed an MCD diet revealed DBP to be among the most differentially expressed proteins (48). Interestingly, a genome-wide association study of 928 adolescents assessed for NAFLD revealed a highly significant association of NAFLD with the single nucleotide polymorphism rs222054 in the group-specific globulin gene $(G C)$, which encodes DBP (49). In relation to these findings, we have demonstrated that liver steatosis is associated with low serum $25(\mathrm{OH}) \mathrm{D}$ concentrations in a cohort of 241 patients with chronic liver diseases, who were assessed non-invasively by controlled attenuation parameter (CAP) to quantify hepatic steatosis (50). In addition, the rare allele of 7-dehydrocholesterol reductase (DHCR7) variant (rs12785878) has also been shown to be associated with increased liver stiffness (51). However, no associations with CAP were found for other common vitamin $\mathrm{D}$ pathway gene variants, namely $G C$ rs7041, cytochrome P450 2R1 (CYP2R1) rs10741657, DHCR7 rs12785878 or VDR rs7974353 (52).

\section{Conclusion}

A growing body of evidence links abnormalities in vitamin D metabolism to fatty liver disease. Although the preclinical models in this review do not replicate the whole spectrum of human disease, they are of relevance in elucidating the roles and pathways of vitamin D and related factors involved in the pathogenesis of NAFLD and NASH, as well as for providing a better mechanistic understanding of the potential of vitamin D-based therapies. However, the utility of these models in verifying hypotheses on disease pathogenesis or intervention studies does not eliminate the need for well-designed clinical trials in (vitamin D-deficient) patients, particularly due to the broad spectrum of alterations in NAFLD.

\section{Conflicts of Interest}

The Authors declare that there are no conflicts of interest regarding the publication of this article. 


\section{Authors' Contributions}

All the Authors contributed in the drafting, intellectual and structural development and critical review of this manuscript.

\section{References}

1 Ludwig J, Viggiano TR, McGill DB and Oh BJ: Nonalcoholic steatohepatitis: Mayo clinic experiences with a hitherto unnamed disease. Mayo Clin Proc 55(7): 434-438, 1980. PMID: 7382552.

2 Younossi ZM, Koenig AB, Abdelatif D, Fazel Y, Henry L and Wymer M: Global epidemiology of nonalcoholic fatty liver disease-meta-analytic assessment of prevalence, incidence, and outcomes. Hepatology 64(1): 73-84, 2016. PMID: 26707365. DOI: 10.1002/hep.28431

3 Kenneally S, Sier JH and Moore JB: Efficacy of dietary and physical activity intervention in non-alcoholic fatty liver disease: A systematic review. BMJ Open Gastroenterol 4(1): 2017-000139, 2017. PMID: 28761689. DOI: 10.1136/bmjgast-2017-000139

4 Abramovitch S, Dahan-Bachar L, Sharvit E, Weisman Y, Ben Tov A, Brazowski E and Reif S: Vitamin d inhibits proliferation and profibrotic marker expression in hepatic stellate cells and decreases thioacetamide-induced liver fibrosis in rats. Gut 60(12): 17281737, 2011. PMID: 21816960. DOI: 10.1136/gut.2010.234666

5 Kitson MT and Roberts SK: D-livering the message: The importance of vitamin d status in chronic liver disease. J Hepatol 57(4): 897-909, 2012. PMID: 22634121. DOI: 10.1016/j.jhep.2012.04.033

6 Arteh J, Narra S and Nair S: Prevalence of vitamin d deficiency in chronic liver disease. Dig Dis Sci 55(9): 2624-2628, 2010. PMID: 19960254. DOI: $10.1007 / \mathrm{s} 10620-009-1069-9$

7 Eliades M, Spyrou E, Agrawal N, Lazo M, Brancati FL, Potter JJ, Koteish AA, Clark JM, Guallar E and Hernaez R: Meta-analysis: Vitamin $\mathrm{d}$ and non-alcoholic fatty liver disease. Aliment Pharmacol Ther 38(3): 246-254, 2013. PMID: 23786213. DOI: 10.1111/apt.12377

8 Wang X, Li W, Zhang Y, Yang Y and Qin G: Association between vitamin $\mathrm{d}$ and non-alcoholic fatty liver disease/non-alcoholic steatohepatitis: Results from a meta-analysis. Int J Clin Exp Med 8(10): 17221-17234, 2015. PMID: 26770315.

9 Geier A, Eichinger M, Stirnimann G, Semela D, Tay F, Seifert B, Tschopp O, Bantel H, Jahn D, Marques Maggio E, Saleh L, Bischoff-Ferrari HA, Mullhaupt B and Dufour JF: Treatment of non-alcoholic steatohepatitis patients with vitamin d: A doubleblinded, randomized, placebo-controlled pilot study. Scand J Gastroenterol 53(9): 1114-1120, 2018. PMID: 30270688. DOI: 10.1080/00365521.2018.1501091

10 Calzadilla Bertot L and Adams LA: The natural course of nonalcoholic fatty liver disease. Int J Mol Sci 17(5), 2016. PMID: 27213358. DOI: $10.3390 /$ ijms 17050774

11 Wong VW, Adams LA, de Ledinghen V, Wong GL and Sookoian $\mathrm{S}$ : Noninvasive biomarkers in nafld and nash - current progress and future promise. Nat Rev Gastroenterol Hepatol 15(8): 461478, 2018. PMID: 29844588. DOI: 10.1038/s41575-018-0014-9

12 Adams JS and Hewison M: Update in vitamin d. J Clin Endocrinol Metab 95(2): 471-478, 2010. PMID: 20133466. DOI: $10.1210 /$ jc. $2009-1773$

13 Wobke TK, Sorg BL and Steinhilber D: Vitamin d in inflammatory diseases. Front Physiol 5(244), 2014. PMID: 25071589. DOI: $10.3389 /$ fphys.2014.00244
14 Wang H, Chen W, Li D, Yin X, Zhang X, Olsen N and Zheng SG: Vitamin d and chronic diseases. Aging Dis 8(3): 346-353, 2017. PMID: 28580189. DOI: 10.14336/AD.2016.1021

15 Stokes CS, Volmer DA, Grunhage F and Lammert F: Vitamin d in chronic liver disease. Liver Int 33(3): 338-352, 2013. PMID: 23402606. DOI: 10.1111/liv.12106

16 Barchetta I, Angelico F, Del Ben M, Baroni MG, Pozzilli P, Morini $\mathrm{S}$ and Cavallo MG: Strong association between non alcoholic fatty liver disease (nafld) and low 25(oh) vitamin d levels in an adult population with normal serum liver enzymes. BMC Med 9(85): 17417015, 2011. PMID: 21749681. DOI: 10.1186/1741-7015-9-85

17 Barchetta I, Carotti S, Labbadia G, Gentilucci UV, Muda AO, Angelico F, Silecchia G, Leonetti F, Fraioli A, Picardi A, Morini S and Cavallo MG: Liver vitamin d receptor, cyp2r1, and cyp27a1 expression: Relationship with liver histology and vitamin d3 levels in patients with nonalcoholic steatohepatitis or hepatitis c virus. Hepatology 56(6): 2180-2187, 2012. PMID: 22753133. DOI: $10.1002 /$ hep. 25930

18 Dasarathy J, Periyalwar P, Allampati S, Bhinder V, Hawkins C, Brandt P, Khiyami A, McCullough AJ and Dasarathy S: Hypovitaminosis $d$ is associated with increased whole body fat mass and greater severity of non-alcoholic fatty liver disease. Liver Int 34(6): 1, 2014. PMID: 24118743. DOI: 10.1111/liv.12312

19 Manco M, Ciampalini P and Nobili V: Low levels of 25-hydroxyvitamin $\mathrm{d}(3)$ in children with biopsy-proven nonalcoholic fatty liver disease. Hepatology 51(6): 2229, 2010. PMID: 20513013. DOI: $10.1002 /$ hep. 23724

20 Nelson JE, Roth CL, Wilson LA, Yates KP, Aouizerat B, MorganStevenson V, Whalen E, Hoofnagle A, Mason M, Gersuk V, Yeh MM and Kowdley KV: Vitamin d deficiency is associated with increased risk of non-alcoholic steatohepatitis in adults with nonalcoholic fatty liver disease: Possible role for mapk and nf-kappab? Am J Gastroenterol 111(6): 852-863, 2016. PMID: 27002799. DOI: 10.1038/ajg.2016.51

21 Nobili V, Giorgio V, Liccardo D, Bedogni G, Morino G, Alisi A and Cianfarani S: Vitamin d levels and liver histological alterations in children with nonalcoholic fatty liver disease. Eur $\mathbf{J}$ Endocrinol 170(4): 547-553, 2014. PMID: 24412930. DOI: 10.1530/EJE-13-0609

22 Targher G, Bertolini L, Scala L, Cigolini M, Zenari L, Falezza G and Arcaro G: Associations between serum 25-hydroxyvitamin d3 concentrations and liver histology in patients with non-alcoholic fatty liver disease. Nutr Metab Cardiovasc Dis 17(7): 517-524, 2007. PMID: 16928437. DOI: 10.1016/j.numecd.2006.04.002

23 Chung GE, Kim D, Kwak MS, Yang JI, Yim JY, Lim SH and Itani $\mathrm{M}$ : The serum vitamin d level is inversely correlated with nonalcoholic fatty liver disease. Clin Mol Hepatol 22(1): 146-151, 2016. PMID: 27044765. DOI: 10.3350/cmh.2016.22.1.146

24 Anty R, Hastier A, Canivet CM, Patouraux S, Schneck AS, Ferrari-Panaia P, Ben-Amor I, Saint-Paul MC, Gugenheim J, Gual P, Iannelli A and Tran A: Severe vitamin d deficiency is not associated with liver damage in morbidly obese patients. Obes Surg 26(9): 2138-2143, 2016. PMID: 26787197. DOI: 10.1007/s11695-016-2070-y

25 Bril F, Maximos M, Portillo-Sanchez P, Biernacki D, Lomonaco R, Subbarayan S, Correa M, Lo M, Suman A and Cusi K: Relationship of vitamin $\mathrm{d}$ with insulin resistance and disease severity in non-alcoholic steatohepatitis. J Hepatol 62(2): 405411, 2015. PMID: 25195551. DOI: 10.1016/j.jhep.2014.08.040 
26 Diez Rodriguez R, Ballesteros Pomar MD, Calleja Fernandez A, Calleja Antolin S, Cano Rodriguez I, Linares Torres P, Jorquera Plaza F and Olcoz Goni JL: Vitamin d levels and bone turnover markers are not related to non-alcoholic fatty liver disease in severely obese patients. Nutr Hosp 30(6): 1256-1262, 2014. PMID: 25433106. DOI: 10.3305/nh.2014.30.6.7948

27 Patel YA, Henao R, Moylan CA, Guy CD, Piercy DL, Diehl AM and Abdelmalek MF: Vitamin $d$ is not associated with severity in nafld: Results of a paired clinical and gene expression profile analysis. Am J Gastroenterol 111(11): 1591-1598, 2016. PMID: 27644736. DOI: 10.1038/ajg.2016.406

28 Ding N, Liddle C, Evans RM and Downes M: Hepatic actions of vitamin d receptor ligands: A sunshine option for chronic liver disease? Expert Rev Clin Pharmacol 6(6): 597-599, 2013. PMID: 24164608. DOI: $10.1586 / 17512433.2013 .841078$

29 Duran A, Hernandez ED, Reina-Campos M, Castilla EA, Subramaniam S, Raghunandan S, Roberts LR, Kisseleva T, Karin M, Diaz-Meco MT and Moscat J: P62/sqstm1 by binding to vitamin $\mathrm{d}$ receptor inhibits hepatic stellate cell activity, fibrosis, and liver cancer. Cancer Cell 30(4): 595-609, 2016. PMID: 27728806. DOI: $10.1016 /$ j.ccell.2016.09.004

30 Hochrath K, Stokes CS, Geisel J, Pollheimer MJ, Fickert P, Dooley S and Lammert F: Vitamin d modulates biliary fibrosis in abcb4-deficient mice. Hepatol Int 8(3): 443-452, 2014. PMID: 25191532. DOI: $10.1007 / \mathrm{s} 12072-014-9548-2$

31 Beilfuss A, Sowa JP, Sydor S, Beste M, Bechmann LP, Schlattjan M, Syn WK, Wedemeyer I, Mathe Z, Jochum C, Gerken G, Gieseler RK and Canbay A: Vitamin d counteracts fibrogenic tgfbeta signalling in human hepatic stellate cells both receptordependently and independently. Gut 64(5): 791-799, 2015. PMID: 25134788. DOI: 10.1136/gutjnl-2014-307024

32 Su D, Nie Y, Zhu A, Chen Z, Wu P, Zhang L, Luo M, Sun Q, Cai L, Lai Y, Xiao Z, Duan Z, Zheng S, Wu G, Hu R, Tsukamoto H, Lugea A, Liu Z, Pandol SJ and Han YP: Vitamin d signaling through induction of paneth cell defensins maintains gut microbiota and improves metabolic disorders and hepatic steatosis in animal models. Front Physiol 7(498), 2016. PMID: 27895587. DOI: $10.3389 /$ fphys.2016.00498

33 Su YB, Li TH, Huang CC, Tsai HC, Huang SF, Hsieh YC, Yang YY, Huang YH, Hou MC and Lin HC: Chronic calcitriol supplementation improves the inflammatory profiles of circulating monocytes and the associated intestinal/adipose tissue alteration in a diet-induced steatohepatitis rat model. PLoS One 13(4), 2018. PMID: 29684027. DOI: 10.1371/journal.pone. 0194867

34 Kong M, Zhu L, Bai L, Zhang X, Chen Y, Liu S, Zheng S, Pandol SJ, Han YP and Duan Z: Vitamin d deficiency promotes nonalcoholic steatohepatitis through impaired enterohepatic circulation in animal model. Am J Physiol Gastrointest Liver Physiol 307(9): 11, 2014. PMID: 25214402. DOI: 10.1152/ajpgi.00427.2013

35 Han H, Cui M, You X, Chen M, Piao X and Jin G: A role of $1,25(\mathrm{oh}) 2 \mathrm{~d} 3$ supplementation in rats with nonalcoholic steatohepatitis induced by choline-deficient diet. Nutr Metab Cardiovasc Dis 25(6): 556-561, 2015. PMID: 25843661. DOI: 10.1016/j.numecd.2015.02.011

36 Feldstein AE, Wieckowska A, Lopez AR, Liu YC, Zein NN and McCullough AJ: Cytokeratin-18 fragment levels as noninvasive biomarkers for nonalcoholic steatohepatitis: A multicenter validation study. Hepatology 50(4): 1072-1078, 2009. PMID: 19585618. DOI: $10.1002 /$ hep. 23050
37 Chow EC, Magomedova L, Quach HP, Patel R, Durk MR, Fan J, Maeng HJ, Irondi K, Anakk S, Moore DD, Cummins CL and Pang KS: Vitamin d receptor activation down-regulates the small heterodimer partner and increases cyp7a1 to lower cholesterol. Gastroenterology 146(4): 1048-1059, 2014. PMID: 24365583. DOI: $10.1053 /$ j.gastro.2013.12.027

38 Li R, Guo E, Yang J, Li A, Yang Y, Liu S, Liu A and Jiang X: $1,25(\mathrm{oh}) 2 \mathrm{~d} 3$ attenuates hepatic steatosis by inducing autophagy in mice. Obesity 25(3): 561-571, 2017. PMID: 28145056. DOI: $10.1002 /$ oby. 21757

39 Yin Y, Yu Z, Xia M, Luo X, Lu X and Ling W: Vitamin d attenuates high fat diet-induced hepatic steatosis in rats by modulating lipid metabolism. Eur J Clin Invest 42(11): 1189-1196, 2012. PMID: 22958216. DOI: 10.1111/j.1365-2362.2012.02706.x

40 Geldenhuys S, Hart PH, Endersby R, Jacoby P, Feelisch M, Weller $\mathrm{RB}$, Matthews $\mathrm{V}$ and Gorman $\mathrm{S}$ : Ultraviolet radiation suppresses obesity and symptoms of metabolic syndrome independently of vitamin d in mice fed a high-fat diet. Diabetes 63(11): 3759-3769, 2014. PMID: 25342734. DOI: $10.2337 / \mathrm{db} 13-1675$

41 Nakano T, Cheng YF, Lai CY, Hsu LW, Chang YC, Deng JY, Huang YZ, Honda H, Chen KD, Wang CC, Chiu KW, Jawan B, Eng HL, Goto $S$ and Chen CL: Impact of artificial sunlight therapy on the progress of non-alcoholic fatty liver disease in rats. $\mathrm{J}$ Hepatol 55(2): 415-425, 2011. PMID: 21184788. DOI: 10.1016/j.jhep.2010.11.028

42 Roth CL, Elfers CT, Figlewicz DP, Melhorn SJ, Morton GJ, Hoofnagle A, Yeh MM, Nelson JE and Kowdley KV: Vitamin d deficiency in obese rats exacerbates nonalcoholic fatty liver disease and increases hepatic resistin and toll-like receptor activation. Hepatology 55(4): 1103-1111, 2012. PMID: 21994008. DOI: 10.1002/hep. 24737

43 Wang H, Zhang Q, Chai Y, Liu Y, Li F, Wang B, Zhu C, Cui J, Qu $\mathrm{H}$ and $\mathrm{Zhu} \mathrm{M}: 1,25(\mathrm{oh}) 2 \mathrm{~d} 3$ downregulates the toll-like receptor 4mediated inflammatory pathway and ameliorates liver injury in diabetic rats. J Endocrinol Invest 38(10): 1083-1091, 2015. PMID: 25906757. DOI: 10.1007/s40618-015-0287-6

44 Bozic M, Guzman C, Benet M, Sanchez-Campos S, GarciaMonzon C, Gari E, Gatius S, Valdivielso JM and Jover R: Hepatocyte vitamin $\mathrm{d}$ receptor regulates lipid metabolism and mediates experimental diet-induced steatosis. J Hepatol 65(4): 748-757, 2016. PMID: 27245430. DOI: 10.1016/j.jhep.2016.05.031

45 Ding N, Yu RT, Subramaniam N, Sherman MH, Wilson C, Rao R, Leblanc M, Coulter S, He M, Scott C, Lau SL, Atkins AR, Barish GD, Gunton JE, Liddle C, Downes M and Evans RM: A vitamin $\mathrm{d}$ receptor/smad genomic circuit gates hepatic fibrotic response. Cell 153(3): 601-613, 2013. PMID: 23622244. DOI: 10.1016/j.cell.2013.03.028

46 Chun RF, Peercy BE, Orwoll ES, Nielson CM, Adams JS and Hewison M: Vitamin d and dbp: The free hormone hypothesis revisited. J Steroid Biochem Mol Biol 144: 132-137, 2014. PMID: 24095930. DOI: 10.1016/j.jsbmb.2013.09.012

47 Olerod G, Hulten LM, Hammarsten O and Klingberg E: The variation in free 25 -hydroxy vitamin $\mathrm{d}$ and vitamin d-binding protein with season and vitamin d status. Endocr Connect 6(2): 111-120, 2017. PMID: 28179376. DOI: 10.1530/EC-16-0078

48 Lee SJ, Kang JH, Iqbal W and Kwon OS: Proteomic analysis of mice fed methionine and choline deficient diet reveals marker proteins associated with steatohepatitis. PLoS One 10(4), 2015. PMID: 25849376. DOI: 10.1371/journal.pone.0120577 
49 Adams LA, White SW, Marsh JA, Lye SJ, Connor KL, Maganga R, Ayonrinde OT, Olynyk JK, Mori TA, Beilin LJ, Palmer LJ, Hamdorf JM and Pennell CE: Association between liver-specific gene polymorphisms and their expression levels with nonalcoholic fatty liver disease. Hepatology 57(2): 590-600, 2013. PMID: 23213074. DOI: 10.1002/hep.26184

50 Jamka M, Arslanow A, Bohner A, Krawczyk M, Weber SN, Grunhage F, Lammert F and Stokes CS: Effects of gene variants controlling vitamin d metabolism and serum levels on hepatic steatosis. Digestion 97(4): 298-308, 2018. PMID: 29514138. DOI: $10.1159 / 000485180$

51 Grunhage F, Hochrath K, Krawczyk M, Hoblinger A, ObermayerPietsch B, Geisel J, Trauner M, Sauerbruch T and Lammert F: Common genetic variation in vitamin $\mathrm{d}$ metabolism is associated with liver stiffness. Hepatology 56(5): 1883-1891, 2012. PMID: 22576297. DOI: $10.1002 /$ hep.25830

52 Erbas O, Solmaz V, Aksoy D, Yavasoglu A, Sagcan M and Taskiran D: Cholecalciferol (vitamin d 3) improves cognitive dysfunction and reduces inflammation in a rat fatty liver model of metabolic syndrome. Life Sci 103(2): 68-72, 2014. PMID: 24727236. DOI: $10.1016 /$ j.lfs.2014.03.035

53 Zhu CG, Liu YX, Wang H, Wang BP, Qu HQ, Wang BL and Zhu $\mathrm{M}$ : Active form of vitamin d ameliorates non-alcoholic fatty liver disease by alleviating oxidative stress in a high-fat diet rat model. Endocr J 64(7): 663-673, 2017. PMID: 28539530. DOI: 10.1507/endocrj.EJ16-0542

54 Giblin RJ, Bennett EJ, Zosky GR and Dwyer RM: The impact of sex and 25(oh)d deficiency on metabolic function in mice. Nutrients 9(9): 985, 2017. PMID: 28880231. DOI: 10.3390/nu9090985

55 Mostafa DK, Nasra RA, Zahran N and Ghoneim MT: Pleiotropic protective effects of vitamin d against high fat diet-induced metabolic syndrome in rats: One for all. Eur J Pharmacol 792: 38-47, 2016. PMID: 27789220. DOI: 10.1016/j.ejphar.2016.10.031

56 Jahn D, Dorbath D, Kircher S, Nier A, Bergheim I, Lenaerts K, Hermanns HM and Geier A: Beneficial effects of vitamin d treatment in an obese mouse model of non-alcoholic steatohepatitis. Nutrients 11(1): 77, 2019. PMID: 30609782. DOI: 10.3390/nu11010077

57 Liu XJ, Wang BW, Zhang C, Xia MZ, Chen YH, Hu CQ, Wang H, Chen X and Xu DX: Vitamin d deficiency attenuates high-fat dietinduced hyperinsulinemia and hepatic lipid accumulation in male mice. Endocrinology 156(6): 2103-2113, 2015. PMID: 25774554. DOI: $10.1210 /$ en.2014-2037
58 Liu L, Lv G, Ning C, Yang YE and Zhu J: Therapeutic effects of 1,25-dihydroxyvitamin $\mathrm{d} 3$ on diabetes-induced liver complications in a rat model. Exp Ther Med 11(6): 2284-2292, 2016. PMID: 27284312. DOI: 10.3892/etm.2016.3242

59 Shojaei Zarghani S, Abbaszadeh S, Alizadeh M, Rameshrad M, Garjani A and Soraya H: The eeffect of metformin combined with calcium-vitamin d3 against diet-induced nonalcoholic fatty liver disease. Adv Pharm Bull 8(1): 97-105, 2018. PMID: 29670844. DOI: $10.15171 / \mathrm{apb} .2018 .012$

60 Shojaei Zarghani S, Soraya $\mathrm{H}$ and Alizadeh M: Calcium and vitamin $\mathrm{d} 3$ combinations improve fatty liver disease through ampkindependent mechanisms. Eur J Nutr 57(2): 731-740, 2018. PMID: 27988847. DOI: 10.1007/s00394-016-1360-4

61 Kheder R, Hobkirk J, Saeed Z, Janus J, Carroll S, Browning MJ and Stover C: Vitamin d3 supplementation of a high fat high sugar diet ameliorates prediabetic phenotype in female $\operatorname{ldl}(-/-)$ and ldlr(+/+) mice. Immun Inflamm Dis 5(2): 151-162, 2017. PMID: 28474500. DOI: 10.1002/iid3.154

62 Abramovitch S, Sharvit E, Weisman Y, Bentov A, Brazowski E, Cohen G, Volovelsky O and Reif S: Vitamin d inhibits development of liver fibrosis in an animal model but cannot ameliorate established cirrhosis. Am J Physiol Gastrointest Liver Physiol 308(2): 11, 2015. PMID: 25214398. DOI: 10.1152/ajpgi.00132.2013

63 Tablas MB, Goto RL, Caetano BFR, dos Santos SAA and Barbisan LF: Vitamin d3 suppresses the early stages of chemically induced hepatocarcinogenesis in rats: A dose-response analysis. Nutrire 43(1): 12, 2018. DOI: 10.1186/s41110-018-0065-2

64 Turner RT, Aloia RC, Segel LD, Hannon KS and Bell NH: Chronic alcohol treatment results in disturbed vitamin $\mathrm{d}$ metabolism and skeletal abnormalities in rats. Alcohol Clin Exp Res 12(1): 159-162, 1988. PMID: 3279849. DOI: 10.1111/j.1530-0277.1988.tb00152.x

65 Trepo E, Ouziel R, Pradat P, Momozawa Y, Quertinmont E, Gervy C, Gustot T, Degre D, Vercruysse V, Deltenre P, Verset L, Gulbis B, Franchimont D, Deviere J, Lemmers A and Moreno C: Marked 25-hydroxyvitamin d deficiency is associated with poor prognosis in patients with alcoholic liver disease. J Hepatol 59(2): 344-350, 2013. PMID: 23557869. DOI: 10.1016/j.jhep.2013.03.024

Received September 11, 2019

Revised September 23, 2019

Accepted September 25, 2019 